\title{
DELIMITAÇÃO E CARACTERIZAÇÃO DE UM TRANSECTO NA VERTENTE DO SUBSISTEMA DE VEREDA NA RESERVA ECOLÓGICA DO IBGE/RECOR-DF
}

\author{
Ane Caroline Amaral Carvalho \\ Mestre em Geografia pela Universidade de Brasília - UnB \\ Brasília, DF, Brasil \\ anecaroline ac@yahoo.com.br \\ Ruth Elias de Paula Laranja \\ Prof ${ }^{\underline{a}}$ Dra. Departamento de Geografia, Universidade de Brasília - UnB \\ Brasília, DF, Brasil \\ uabruth@gmail.com \\ Roselir de Oliveira Nascimento \\ Prof ${ }^{\underline{a}}$ Dra. Departamento de Geografia, Universidade de Brasília - UnB \\ Brasília, DF, Brasil \\ roselir@unb.br \\ Fernanda Pereira Rodrigues \\ Bacharel em Geografia pela Universidade de Brasília - UnB \\ Brasília, DF, Brasil \\ fernanda.p.rodrigues@gmail.com
}

\begin{abstract}
RESUMO
A Vereda corresponde a um importante subsistema do bioma Cerrado, cuja manutenção do seu equilíbrio é fundamental para a perenidade dos recursos hídricos. Diante disso, o objetivo deste estudo é conhecer os condicionantes ambientais responsáveis pelo desenvolvimento e evolução da Vereda na paisagem e delimitar suas zonas morfológicas, tendo como estudo de caso a Reserva Ecológica do IBGE (RECOR), Distrito Federal. Para tanto, foi selecionado um transecto perpendicular à linha de drenagem da Vereda, onde foram reconhecidas zonas distintas com base nas variações nas características topográficas, do solo e da vegetação: envoltório, de umidade sazonal, seca e encharcada. Seguindo o traçado do transecto foram realizadas tradagens, uma em cada zona, para amostragem dos tipos de solo. O levantamento florístico foi realizado pelo método expedito de caminhamento. Na zona Envoltório ocorre o Latossolo Vermelho associado ao cerrado ralo; na Zona de umidade Sazonal identificou-se o Latossolo Vermelho-Amarelo e o campo limpo e; na Zona Encharcada a Vereda. As famílias com maior número de espécies foram Melastomataceae, Cyperaceae, Lycopodiaceae e Poaceae. A diferenciação da vegetação, com a substituição das espécies vegetais típicas de Vereda por outras adaptadas a solos menos úmidos são indicadores de um processo de alteração ambiental.
\end{abstract}

Palavras-chave: Vereda. Solo. Composição florística. Zonas Morfológicas. Alteração ambiental.

\section{DELIMITATION AND CHARACTERIZATION OF A TRANSECT IN THE SLOPE OF THE SUBSYSTEM VEREDA IN THE RESERVE OF THE IBGE/RECOR-DF}

\begin{abstract}
The Vereda corresponds to a very important subsystem of the Cerrado biome, whose maintenance of their balance is fundamental for the perennial water resources. Therefore, the main objective of this study is to understand the environmental conditioners responsible for the development and evolution of the vereda in the landscape and delimit its morphological zones, the case of study is a Vereda located in the Reserve Of the IBGE (RECOR), Distrito Federal. For that, it was selected a transect perpendicular to the drainage line of the Vereda, where distinct zones were recognized based on the variations in topographic, soil and vegetation characteristics: wrap, seasonal humidity, dry and soaked. Following the trajectory of the transect were taken out samples of the soil with drilling tecniques, one in each zone. The floristic survey was performed by the expedited walking method. In the Wrap Zone occurs the Red Latosol associated with the less dense cerrado; in the Zone of Seasonal humidity was identified as the Red-Yellow Latosol and the clean field; in the Vereda Soaked Zone. The biggest species families were Melastomataceae,
\end{abstract}


Cyperaceae, Lycopodiaceae and Poaceae. The vegetation differentiation with substitution of the typical vegetable species of Vereda by other adapted to less humid soils are indicators of a process of environmental change.

Key words: Vereda. Soil. Floristic composition. Morphological Zones. Environmental change.

\section{INTRODUÇÃO}

O Domínio do Cerrado é composto por um conjunto diversificado de componentes geoambientais que Ihe confere particularidades. Além de estar presente no Planalto Central Brasileiro, também é encontrado em áreas disjuntas dentro de outros domínios morfoclimáticos, o que determina grande influência em sua biogeografia e na diversidade fauno-florística. Devido a essa diversidade, a vegetação do Cerrado apresenta diferentes fisionomias, que englobam formações florestais, savânicas e campestres (RIBEIRO E WALTER, 2008).

Na formação savânica é comum a presença da fitofisionomia Vereda, comunidade vegetal, localizada em áreas planas, encharcadas, com a presença de espécies vegetais herbáceo-arbustivas e da palmeira buriti, Mauritia flexuosa L. f. Essas áreas úmidas que, localizam-se em porções deprimidas do relevo, funcionam como represas naturais da água armazenada nas chapadas, sendo importante para o ciclo hidrológico do Cerrado.

A Vereda, de modo geral, é uma paisagem típica do Cerrado, que se desenvolve em locais com condições ideais de umidade do solo, associados, geralmente, a exsudação do lençol freático e áreas de nascentes de pequenos cursos d'água. Sua ocorrência pode estar relacionada a áreas de relevo mais plano e planícies aluviais de vales pouco profundos, geralmente de fundo chato com solos mal drenados ricos em matéria orgânica. Entretanto esta não é a única forma de ocorrência de Vereda na paisagem, existem diferentes modelos geomorfológicos que apresentam diversidades em suas características hidrológicas, geomorfológicas e fitofisionômicas. As Veredas ocorrem desde associações com drenagens lineares e concentradas classificadas como sendo Veredas de cordão linear, quanto associadas a nascentes onde a drenagem é difusa correspondendo a Vereda de Anfiteatro (MARTINS et al. 2017).

As áreas que envolvem as Veredas também apresentam características que as diferenciam. De acordo com Melo (2008), ao longo das vertentes dos vales onde ocorrem as Veredas há diferentes ambientes, caracterizados por seus aspectos hidrológicos, topográficos, pedológicos e vegetais. A partir dessas características a autora subdividiu a vertente em quatro zonas morfológicas (FIGURA 1):

- Zona do envoltório: corresponde às bordas de superfície tabular que contornam as Veredas. Caracteriza-se pela cobertura vegetal de cerrado e pelo solo areno-quartzoso. Limita-se àruptura de declive que marca o início das vertentes;

- Zona seca: situa-se nas vertentes revestida por gramíneas. Possui solo hidromórfico de textura fina com mosqueamentos, o que indica a sazonalidade do lençol freático;

- Zona encharcada: é o fundo plano da Vereda preenchido por uma camada de turfa de aproximadamente $20 \mathrm{~cm}$, sobre o solo de cor preta. Destaca-se a presença de gramíneas e no centro há a presença de buritis;

- Zona do canal: compreende ao canal de drenagem, onde há o escoamento superficial da água sobre o solo turfoso. A jusante, o talvegue apresenta pouca profundidade que aumenta à medida que se afasta da nascente.

Devido às características geomorfológicas e morfológicas, além de ser uma represa natural responsável por manter a perenização dos rios que estão à jusante deste sistema, as Veredas constituem-se como corredor ecológico. A preservação dessas áreas contribui para a circulação de animais entre os remanescentes florestais, fornecimento de alimento e refúgio para diversas espécies da fauna, além de resguardar exemplares da flora do Cerrado, muitas vezes endêmicas (MARTINS, 2010).

$\begin{array}{llllll}\text { Caminhos de Geografia } & \text { Uberlândia - MG } & \text { v. 19, n. 68 } & \text { Dez/2018 } & \text { p. 233-249 Página } 234\end{array}$


Figura 1:Divisão em zonas que constituem a estrutura morfológica das Veredas de Superfície Tabular propostas por Melo (2008).

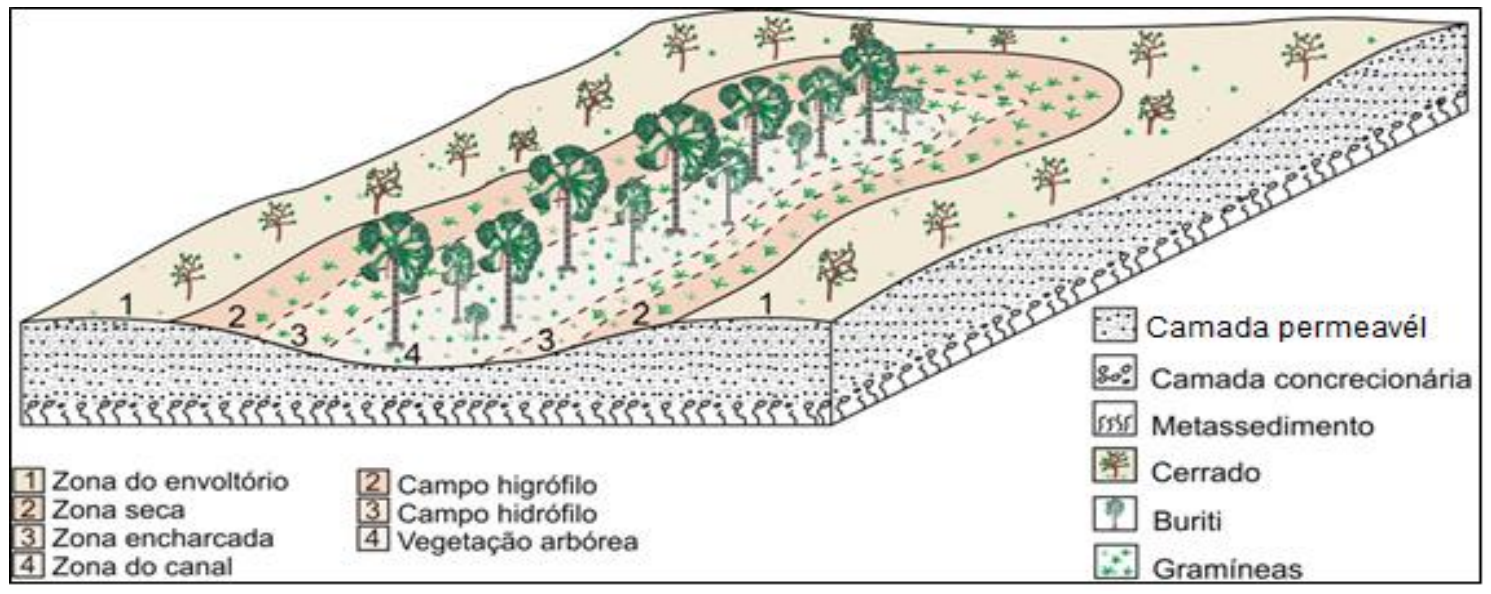

Fonte: SANTOS (2010).

Por ser um ambiente importante para a manutenção do equilíbrio ambiental, sensível às alterações e de baixa capacidade regenerativa, a Vereda é considerada Área de Preservação Permanente (APP), sendo protegida por leis federais, estaduais e municipais. De acordo com a lei o 12.651 de 2012, são consideradas APP em Veredas a faixa marginal, em projeção horizontal, com largura mínima de cinquenta metros, a partir do espaço brejoso e encharcado.

No entanto, apesar de todo o aparato legal, observa-se que esse ambiente continua sendo pressionado e alterado, em decorrência da inexistência de demarcações oficiais das APPs, que poderiam vetar o uso indevido desse ambiente, além da deficiência estrutural do Estado, que impossibilita a efetiva fiscalização.

Embora esse subsistema seja fundamental para o equilíbrio hídrico e ambiental do Cerrado há uma carência de informações sobre suas peculiaridades no Distrito Federal. Por esse motivo, este estudo teve por objetivo analisar em escala de detalhe uma Vereda em Unidade de Conservação, com o intuito de conhecer alguns dos condicionantes ambientais responsáveis pelo seu desenvolvimento na paisagem e assim delimitar suas zonas morfológicas e identificar o seu processo de evolução ecológica.

A análise foi realizada a partir da delimitação de um transecto ao longo da vertente da Vereda em estudo. Esse foi definido considerando a estrutura e dinâmica das comunidades vegetais através do qual se constatou que existe uma intrínseca relação entre litologia, relevo, solos e vegetação.

\section{ÁREA DE ESTUDO}

A Reserva Ecológica do IBGE (RECOR) foi criada em 1975 e compõe o mosaico de áreas protegidas do Distrito Federa (DF) conhecido como APA do Planalto. Está localizada na região centro-sul do DF a $35 \mathrm{Km}$ de Brasília, nas coordenadas geográficas de 1556' 41" S e 475ㅜ 53"W, e possui uma área de aproximadamente 1.350 hectares (FIGURA 2).

Algumas características ambientais são fundamentais para o surgimento e manutenção do subsistema de Vereda no Cerrado, como por exemplo, o clima, o relevo e o solo. O clima no Distrito Federal é caracterizado como, tropical úmido de savana com inverno seco $(A w)$, que se encontra associado às superfícies com cotas altimétricas inferiores a $1.000 \mathrm{~m}$. O tipo Tropical de Altitude (Cwa) associa-se aos locais com cotas entre 1.000 e $1.200 \mathrm{~m}$ e; o Tropical de Altitude (Cwb) as áreas das Chapadas, acima de 1.200 metros.

A RECOR localiza-se na porção sudoeste do domo estrutural de Brasília, esculpido em rochas do Grupo Paranoá, dividida em duas unidades: Formação Ribeirão Gama e Formação Cristo Redentor, com predomínio do metarritmito arenoso.

$\begin{array}{llllll}\text { Caminhos de Geografia } & \text { Uberlândia - MG } & \text { v. 19, n. } 68 & \text { Dez/2018 } & \text { p. 233-249 } & \text { Página } 235\end{array}$


O relevo é suavemente ondulado, com encosta de declividade suave, e associado diretamente à rede de drenagem, apresentando vales abertos e de baixa declividade. As superfícies mais elevadas da Reserva correspondem aos residuais de aplainamento com altitudes entre 1.100 a 1.196 metros. Essas superfícies planas estão associadas aos Latossolos Vermelhos e aos Latossolos VermelhosAmarelos que, geralmente, se sobrepõem a uma camada de couraça laterítica de espessura variável.

Figura 2: Localização da RECOR no território do Distrito Federal

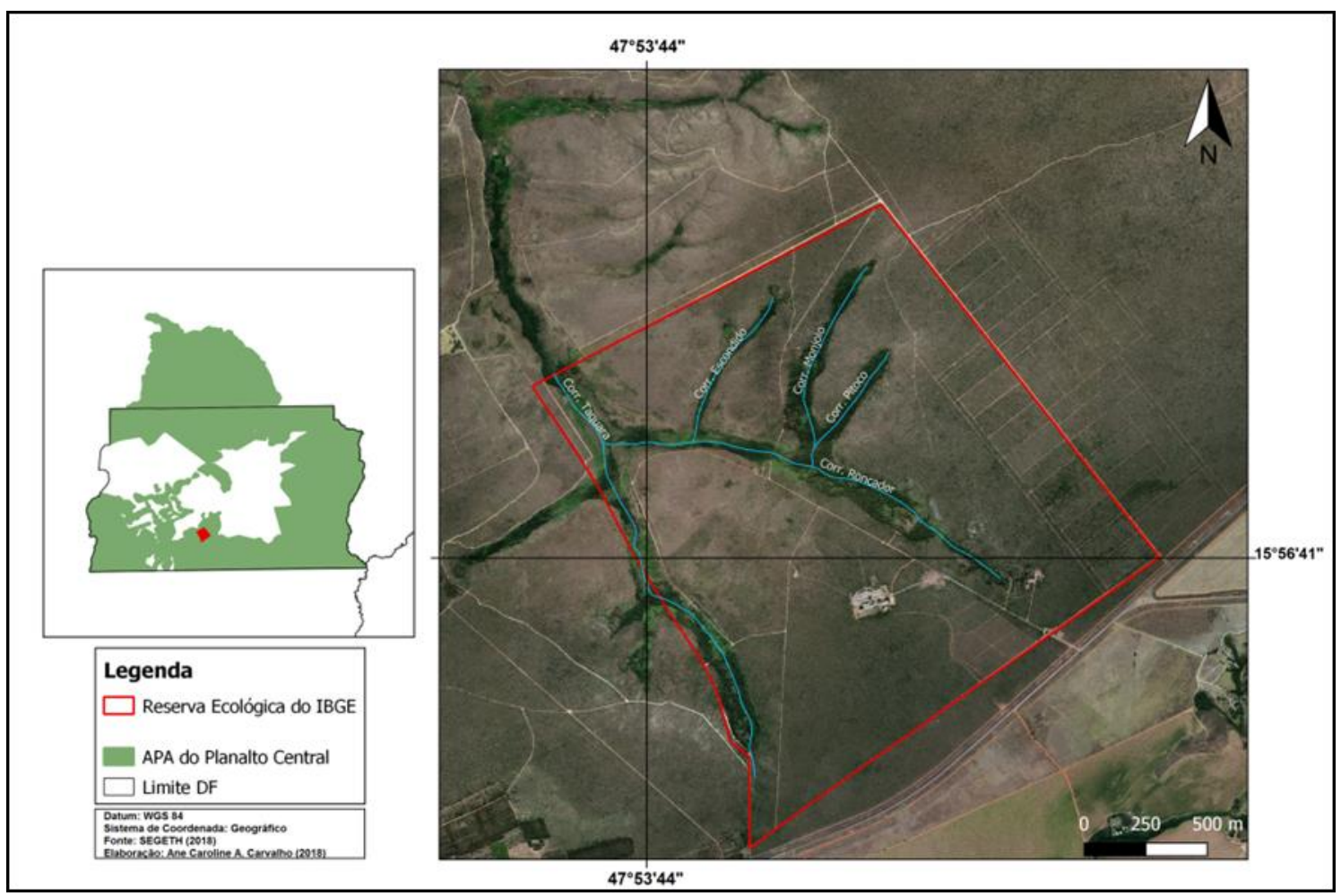

Fonte: SEGETH (2018); Elaboração: Autores (2018).

As planícies e terraços aluviais constituem planos recobertos por materiais detrítico e orgânico, depositados ao longo dos vales. São feições resultantes da acumulação de depósitos fluviais, podendo estar submetidas a inundações periódicas, em função do seu posicionamento topográfico. Essas áreas são formadas por sedimentos muito argilosos, orgânicos e turfosos, resultantes das diferentes fases da evolução holocênica da planície. Os solos são recentes, pertencendo ao grupo dos hidromórficos: Solos Orgânicos e Gleissolo (MAMEDE, 1999).

No tocante a hidrografia, dentro dos limites da RECOR encontra-se a bacia do Córrego Taquara, afluente do ribeirão do Gama contribuinte do Lago Paranoá. Essa bacia está representada pelo próprio córrego Taquara e seus afluentes, pela margem direita: os córregos Taperas, Taperinha e Roncador e pela margem esquerda os córregos Sem Nome e da Onça.

De acordo com Mamede (1999), os cursos d'água dessa bacia surgiram a partir da conexão de antigas depressões rasas associadas ao processo de subsidência da superfície. Essas depressões alinhavam-se aos sistemas de fraturas e falhas do substrato rochoso, que possibilitaram a convergência das águas superficiais, que passaram a escoar de forma concentrada interligando assim estas depressões.

A interligação das pequenas depressões, provavelmente, ocorreu através do escoamento superficial das águas da chuva ou do extravasamento do lençol subsuperficial formando drenos pouco profundos. Ao sair dessas áreas, a água provocou a erosão das margens pelo turbilhonamento, iniciando a erosão remontante nas bordas. Nesse ambiente, devido à presença de umidade e de hidromorfismo criou-se condições ideais para o desenvolvimento de vegetação típica do ambiente de Vereda. Na RECOR além das Veredas existem outras fitofisionomias do Cerrado, como Mata de Galeria, Cerrado ralo e as formações campestres.

\begin{tabular}{llllll}
\hline Caminhos de Geografia & Uberlândia - MG & v. 19, n. 68 & Dez/2018 & p. 233-249 & Página 236
\end{tabular}




\section{PROCEDIMENTOS METODOLÓGICOS}

O trabalho foi dividido em duas etapas representadas pela atividade de campo e o processamento da informação em laboratório. Os campos foram realizados durante o período de seca, pois a intenção era observar se havia ou não a presença de umidade no solo durante esse período. A atividade de campo teve como objetivo observar, reconhecer e analisar as características geoambientais das Veredas (relevo, solo, umidade e vegetação), identificando assim suas tipologias de acordo com o seu posicionamento na paisagem, correlacionando-os com o referencial teórico estudado.

O local selecionado para a demarcação do transecto foi a margem direita do córrego Taquara, entre as Coordenadas Geográficas (Ponto 1: -47.89425, -15.94686; Ponto 2: -47.89135,

$-15.94452$ Ponto 3: $-47.88385,-15.94663)$. Para a escolha desse local levou-se também em consideração a diferença da fitofisionomia características das zonas do subsistema de Vereda e da diferença topografia da vertente. Para a divisão das zonas (Envoltório, de umidade sazonal e encharcada) ao longo do transecto foram consideradas a topografia, o solo e a variação visual da estrutura da vegetação.

A mesma transeção serviu como base para o levantamento florístico. Para a realização dessa etapa, utilizou-se o método do Caminhamento, o qual consiste em três etapas: o reconhecimento dos tipos de vegetação na área amostrada, a elaboração da lista das espécies encontradas a partir de caminhadas aleatórias ao longo de uma ou mais linhas imaginárias e a análise dos resultados (FILGUEIRAS et al., 1994).

Para a identificação dos solos, foram realizadas perfurações com trado manual em três pontos diferentes (topo, meio da encosta e fundo do vale). Para cada perfuração, foram retiradas quatro amostras deformadas, em profundidades variáveis $(0-20 \mathrm{~cm} ; 40-60 \mathrm{~cm} ; 60-80 \mathrm{~cm} ; 80-100 \mathrm{~cm})$ (Figura 3). Conforme as amostras eram retiradas, examinava-se a coloração com base na tabela de Munsell.

Figura 3: Localização do Transecto e pontos de coleta de amostras deformadas de solo na Vereda da RECOR.

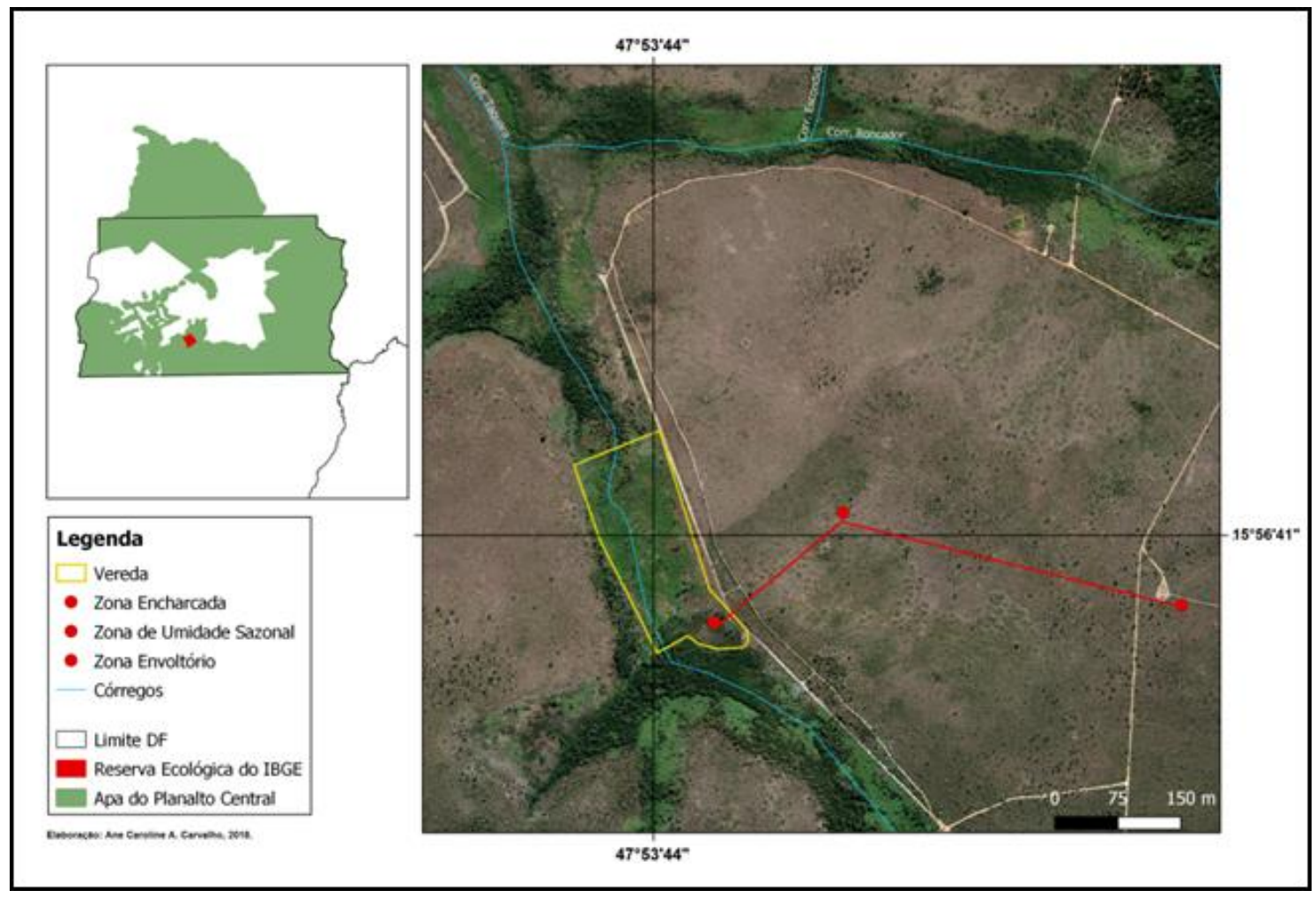

Fonte: SEGETH (2018); Elaboração: Autores (2018). 
Posteriormente, as amostras foram encaminhadas para laboratório, onde foram analisadas suas propriedades granulométricas, baseado no método de Dispersão Total conforme Embrapa (1997).

Os parâmetros químicos analisados foram $\mathrm{P}, \mathrm{K}, \mathrm{Ca}, \mathrm{Mg}, \mathrm{Na}$ e Al elencados com intuito de se verificar a concentração de nutrientes no solo, que está relacionada com a sua fertilidade e a distribuição da vegetação.

\section{RESULTADOS E DISCUSSÃO}

As Veredas na RECOR, na maioria dos casos, estão associadas aos cursos d'água não muito encaixados da bacia do córrego Taquara. Elas ocorrem em disjunções, em forma de Cordão Linear nas planícies de inundação. O conceito de Vereda de Cordão Linear foi descrito por Ferreira (2005/2006) como um modelo geomorfológico que se desenvolve nas margens de cursos de água de médio porte, formando um cordão linear associado a uma vegetação ciliar e/ou galeria em áreas sedimentares. No entanto, na área da RECOR observou-se que esse modelo de Vereda não está restrito aos cursos d'água de médio porte, ocorrendo também associado aos cursos de pequeno porte.

A área da Vereda em estudo não ocupa totalmente a planície fluvial do córrego Taquara, mas aparece como uma faixa paralela à Mata de Galeria Paludosa, onde a umidade do solo também provém do córrego Taquara. Ou seja, no modelo geomorfológico Cordão Linear, a umidade que favorece o desenvolvimento do subsistema de Vereda pode ser proveniente do curso de água e, não necessariamente, do extravasamento do lençol.

Entretanto, como a Vereda em análise está localizada em uma área onde o vale é amplo e plano, além de estar em contato com a umidade proveniente do córrego, o seu solo também permanece saturado devido à presença do lençol freático superficial. Isso ocorre devido ao local do canal de drenagem ainda não possuir um escoamento bem definido, capaz de drenar toda a água pluvial que entra no sistema. Nesse caso, o excesso de umidade no solo apenas desaparece quando o período de estiagem se prolonga além do normal, que geralmente é, em média, de 4 a 5 meses, no Distrito Federal (RIBEIRO, 2011, p. 92).

Pelo fato de a Vereda estar associada a um canal fluvial, foi necessário adaptar a zoneação em subunidades, conforme proposta de Melo (2008) a este contexto. Portanto, a Vereda foi subdividida em Zona Envoltório (superfície tabular que contorna a Vereda); Zona de umidade Sazonal (borda da Vereda até a média vertente) e; Zona Encharcada (o fundo brejoso e encharcado).

Ao longo da vertente analisada, como pode ser verificado no perfil topográfico, figuras 4 e 5 , identificou-se três domínios pedogenéticos diferenciados pela vegetação, solos e topografia. O terço superior (zona de envoltório) é representado por Latossolo Vermelho; um segundo domínio (zona de umidade sazonal) é representado por Latossolo Vermelho-Amarelo e no terço inferior ocorre o domínio com hidromorfia permanente (zona encharcada) com a ocorrência de horizonte superficial rico em matéria orgânica.

Figura 4: Perfil topográfico transversal Vereda da RECOR.

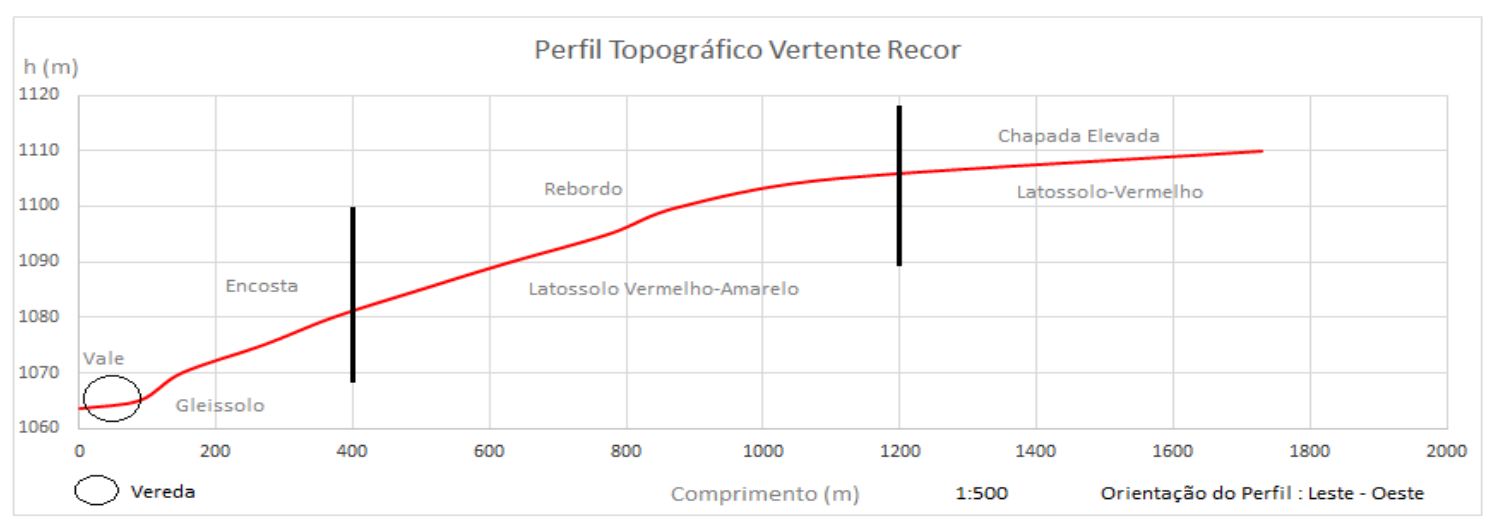

Fonte: CARVALHO (2015, pg. 98). 
Figura 5: Representação das Zonas Morfológicas na Vereda da RECOR.

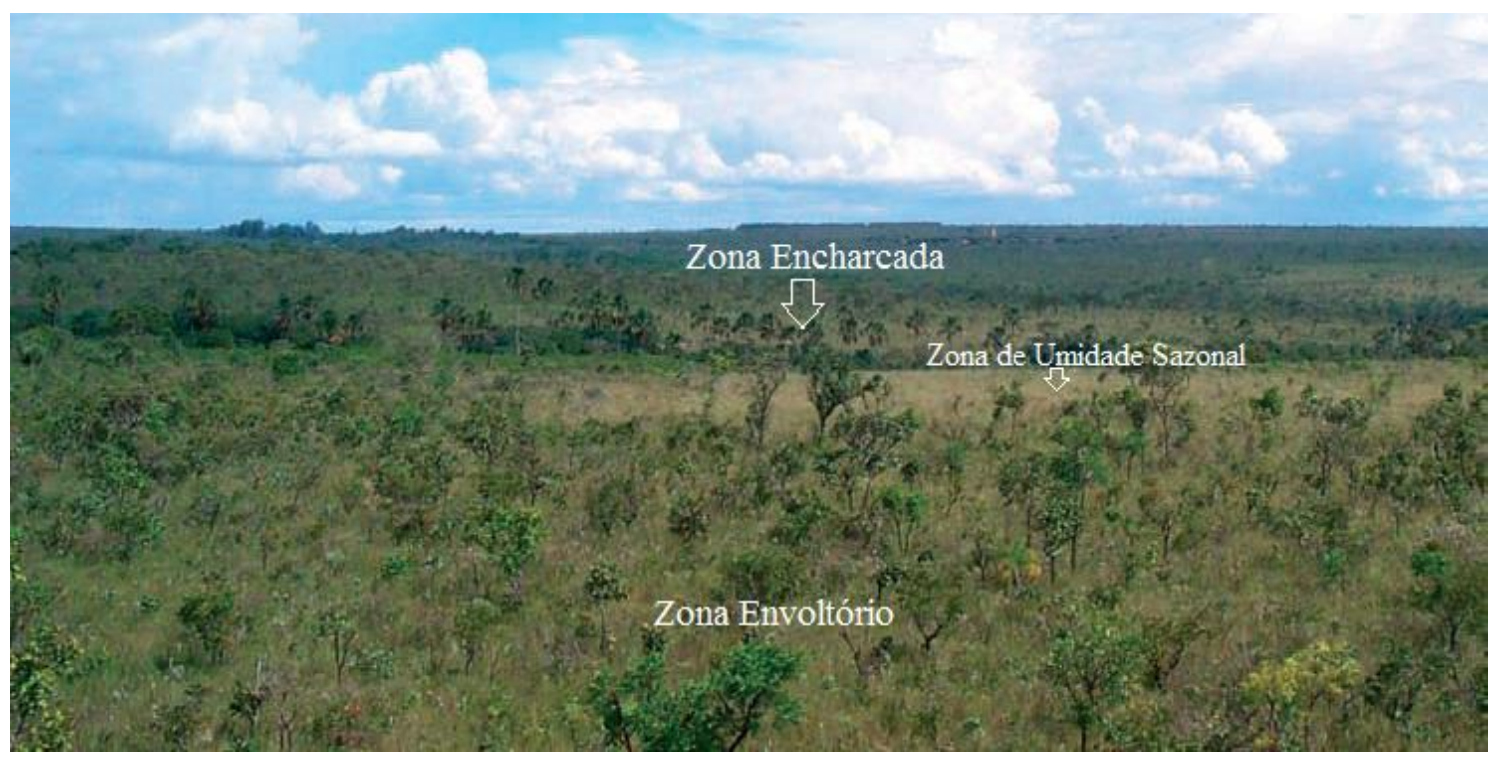

Fonte: RIBEIRO (2015).

A Vereda ocorre sobre um vale aberto de fundo plano, com vertentes de inclinação suave, que correspondem aos Rebordos, superfícies rebaixadas pelo entalhamento promovido pelo córrego Taquara. Essa área possui um baixo desnível topográfico, localizada, aproximadamente, entre as cotas altimetrias de 1.071 a 1.055 metros.

As planícies que compreendem as várzeas e os terraços fluviais do córrego Taquara possuem forma alongada com largura variável e sujeita à dinâmica do vale. Trata-se de superfícies resultantes da acumulação fluvial, contendo depósitos atuais e subatuais. Essas áreas estão sujeitas ou não a inundações periódicas, cujo escoamento fluvial oscila de acordo com os índices pluviométricos (RIBEIRO, 2011).

O solo da zona encharcada é rico em matéria orgânica, às vezes turfoso de acumulação recente e pertencem à classe do Gleissolo. Devido à proximidade do lençol freático e à topografia plana, o solo permanece saturado praticamente o ano todo, o que favorece a existência de uma gradiente edáfico o qual contribui para o aparecimento de comunidades vegetais típica de solos mal drenados.

A camada herbácea da Vereda é dominada por gramíneas, como as espécies, Andropogon bicornis L., Panicum subti ramulosum Renvoize \& Zuloaga, Paspalum proximum. A família Cyperaceae também é importante nessa camada, principalmente através dos espécimes: Bulbostylis capillaris, Lagenocarpus rigidus, Eleocharis filiculmis. Outras espécies de pequeno porte permeiam as gramíneas e conferem riqueza à vegetação (Lycopodiella camporum, B. brasiliensis, Microlicia euphorbioides, Habenaria sp.), além de plantas carnívoras, dos gêneros Drosera e Utricularia.

Verificou-se a presença de elementos herbáceos de porte mais elevado, como os Echinodorus grandiflorus (Cham. \& Schltdl.) Micheli, Ludwigia octovalvis (Jacq) P.H. Raven, Philodendron uliginosum Mayo, além da ocorrência de espécies lenhosas entre a comunidade vegetal da Vereda. De acordo com Pereira e Furtado, o ingresso dessas espécies de formação florestal, aumentou após os incêndios de 1994 e 2005, mas outros fatores devem estar envolvidos na mudança da dinâmica dessa comunidade vegetal (apud. RIBEIRO, 2011).

Sabe-se que um incêndio ocorrido em 2012 na RECOR também atingiu a Vereda, por isso, durante as atividades de campo, observou-se que a vegetação se encontrava bem devastada, 0 que contribuiu para o avanço da espécie Melinis minutiflora $\mathrm{P}$. Beauv. em direção à zona encharcada. $\mathrm{A}$ capacidade de estabelecimento dessa camada rasteira, após essa queimada, pode estar relacionada aos baixos requisitos nutricionais dessa espécie e à facilidade de dispersão de suas sementes (HARIDASAN, 2008).

Além dos impactos decorrentes dos incêndios, a Vereda apresenta uma concentração considerável de espécies lenhosas típicas de Mata de Galeria. Essas espécies ocorrem entre os agrupamentos de

$\begin{array}{llllll}\text { Caminhos de Geografia } & \text { Uberlândia - MG } & \text { v. 19, n. } 68 & \text { Dez/2018 } & \text { p. 233-249 } & \text { Página } 239\end{array}$


Mauritia flexuosa Mart. (buritis), que ainda apresenta indivíduos de diferentes idades, o que permite classificá-la como subsistema de Vereda (Figura 6).

Figura 6: Vereda associada a Mata Galeria Paludosa

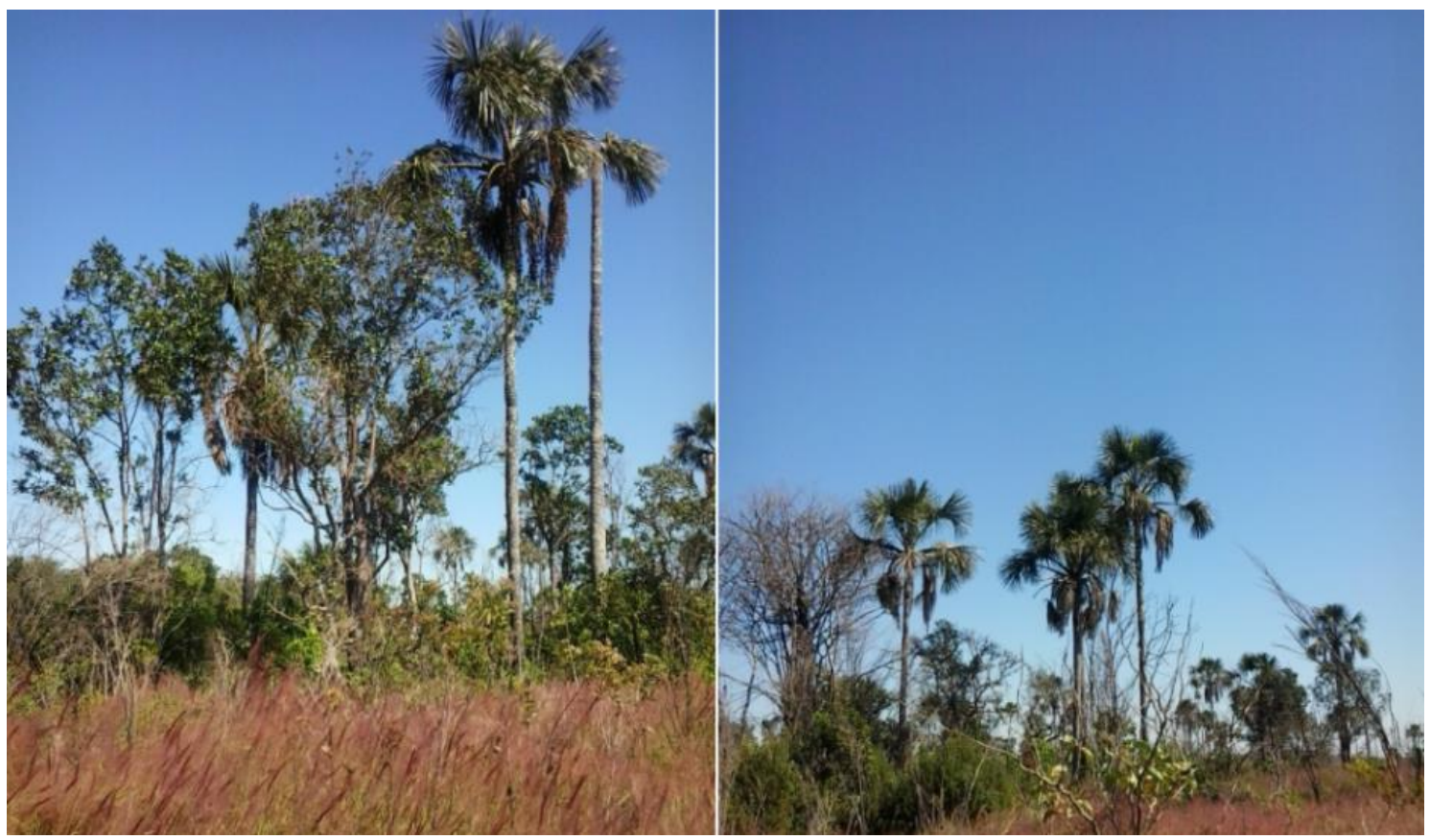

Fonte: CARVALHO (2015).

\section{ATRIBUTOS FísICOS E QUÍMICOS DOS SOLOS}

A partir do que foi verificado em campo e dos resultados das amostras coletadas, constatou-se a ocorrência de Latossolo Vermelho (zona envoltório), Latossolo Vermelho - Amarelo (zona de umidade sazonal) e Gleissolo (zona encharcada). Os principais atributos físicos das 12 amostras de solos, que representam as diferentes zonas da Vereda, encontram-se na Tabela 1.

Quanto à composição granulométrica, a fração argila é predominante nos Latossolos, mas com pouca variação dos teores ao longo do gradiente (40 a 52 \%). Assim, os perfis do Latossolo Vermelho e do Latossolo Vermelho-Amarelo enquadram-se na classe textural argilosa. Algo particular foi identificado na análise física das amostras de Gleissolo, que apresentaram baixos teores de argila e textura franco-arenosa.

Observou-se que as amostras da zona encharcada apresentaram material muito pegajoso, com presença de raízes e restos vegetais abundantes no horizonte superficial e moderada nas camadas adjacentes. A coloração foi a mesma para todas as amostras Glei 2 2.5/10, segundo Munsell (1975).

A fração areia apareceu com concentração moderada em quase todos os níveis, variando apenas no primeiro nível do Gleissolo (> 60\%). Verificou-se que o teor de silte se manteve estável ao longo de todos os perfis, já a baixa relação silte/argila $(0,03$ a 0,06$)$ apresentada pelos Latossolos, demonstra o avançado grau de intemperismo desse solo (EMBRAPA, 2009).

$\mathrm{Na}$ tradagem realizada no Latossolo Vermelho-Amarelo (Zona de umidade sazonal), a partir dos 40 $\mathrm{cm}$ de profundidade, encontrou-se resíduos da couraça e teores mais elevados de argila. $\mathrm{O}$ que, de acordo com Mamede (1999), leva a supor que a couraça, em eras passadas, tenha sido mais espessa. Essas foram transformadas nos solos argilosos atuais, a partir da ação de processos pedogenéticos compatíveis com as condições ambientais tropicais. 
Tabela 1: Análises granulométricas dos solos avaliados no transecto na RECOR.

\begin{tabular}{|c|c|c|c|c|c|}
\hline Profundidade $(\mathrm{cm})$ & $\begin{array}{l}\text { Areia } \\
(\%)\end{array}$ & $\begin{array}{l}\text { Silte } \\
(\%)\end{array}$ & $\begin{array}{l}\text { Argila } \\
\text { (\%) }\end{array}$ & $\begin{array}{l}\text { Silte/Argila } \\
(\%)\end{array}$ & Classificação Textural \\
\hline \multicolumn{6}{|c|}{ Ponto 1: LatossoloVermelho } \\
\hline $0-20$ & 42 & 17 & 40 & 0,04 & Argilosa \\
\hline $40-60$ & 30 & 17 & 52 & 0,03 & Argilosa \\
\hline $60-80$ & 27 & 20 & 52 & 0,03 & Argilosa \\
\hline $80-100$ & 35 & 25 & 40 & 0,06 & Argilosa \\
\hline \multicolumn{6}{|c|}{ Ponto 2: LatossoloVermelho-Amarelo } \\
\hline $0-20$ & 42 & 17 & 40 & 0,04 & Argilosa \\
\hline $40-60$ & 32 & 22 & 45 & 0,05 & Argilosa \\
\hline $60-80$ & 30 & 22 & 47 & 0,04 & Argilosa \\
\hline $80-100$ & 20 & 30 & 50 & 0,06 & Argilosa \\
\hline \multicolumn{6}{|l|}{ Ponto 3: Gleissolo } \\
\hline $0-20$ & 62 & 17 & 20 & 0,08 & Franco -arenosa \\
\hline $40-60$ & 52 & 30 & 17 & 0,1 & Franco -arenosa \\
\hline $60-80$ & 47 & 30 & 22 & 0,1 & Franco -arenosa \\
\hline $80-100$ & 47 & 35 & 17 & 0,2 & Franco -arenosa \\
\hline
\end{tabular}

Fonte: CARVALHO (2015, pg. 93).

Com relação à profundidade de $60 \mathrm{~cm}$, as amostras de Latossolo Vermelho-Amarelo apresentaram umidade, mas não se encontravam saturadas. Segundo Mamede (1999), em profundidade, os horizontes desses Latossolos possuem altas taxas de umidade e saturação em água, possivelmente aliados à proximidade da couraça. A água circula livre pelos horizontes pedológicos da cobertura latossólica, até chegar a zona de alteração onde os fluxos hídricos se modificam. Nesse setor, a água, ao encontrar a camada mais impermeável, muito argilosa ou a própria couraça, concentra-se formando um lençol freático, que passa a escoar lateralmente, até aflorar na área de Vereda.

Com o objetivo de verificar se a concentração de nutrientes estava diretamente relacionada com a distribuição da vegetação ao longo do transecto, realizou-se a análise dos componentes químicos dos solos, cujos resultados estão dispostos na Tabela 2.

Foi analisado que os valores de acidez apresentaram-se elevados em níveis de $\mathrm{pH}$ baixo, variando de 2,5 a $12,1 \mathrm{mE} / 100 \mathrm{ml}$. O pH, ao longo do transecto, demonstrou baixa variabilidade.

Como pode ser verificado na tabela 2 , os teores de Magnésio $(\mathrm{Mg})$ e de Cálcio ( $\mathrm{Ca})$ foram considerados baixos em todos os solos analisados, assim como o de Potássio (K) e de Sódio $(\mathrm{Na})$. A concentração de Fósforo (P) também se apresentou baixa e com bastante irregularidade entre os níveis dos solos. Entretanto, no fundo da Vereda, a concentração de $\mathrm{P}$ nos primeiros $20 \mathrm{~cm}$ foi média.

Em relação aos níveis de Alumínio (Al), os Latossolos tiveram de baixa a média concentração, mas, em compensação, o Gleissolo apresentou níveis elevados (2,7 a 9,8 mE/100ml).

Os valores de Soma de Bases (SB) e CTC decrescem com a profundidade, juntamente com o decréscimo dos teores de matéria orgânica. Apenas nos Gleissolos, o CTC aumentou nos horizontes subsuperficiais. Todas as amostras estudadas também apresentaram baixa saturação por bases $(\mathrm{V}<$ $50 \%$ ). Nos Latossolos isso ocorre, provavelmente, em decorrência do continuo processo de ciclagem de nutrientes nos horizontes superficiais.

A saturação por Alumínio (m \%) variou muito, de 0 a 96,2\%. Os maiores valores de mestão na zona encharcada (solo álico), cujo percentual aumenta em profundidade. Como consequência da alta saturação por alumínio, os níveis de cálcio, magnésio e potássio, bem como a daSoma de Bases são inferiores aos dos Latossolos. 
Tabela 2: Atributos químicos dos solos do transecto da Vereda da RECOR.

\begin{tabular}{|c|c|c|c|c|c|c|c|c|c|c|c|c|c|}
\hline \multirow{2}{*}{$\begin{array}{l}\text { Profundidade } \\
\text { (cm) }\end{array}$} & \multirow{2}{*}{$\mathrm{pH} \mathrm{H}_{2} \mathrm{O}$} & \multirow{2}{*}{$P\left(\mathrm{mg} / \mathrm{dm}^{3}\right)$} & $\mathrm{Ca}+\mathrm{Mg}$ & Al & H + Al Acidez & $\mathrm{Na}$ & K & $\mathbf{T}$ & SB & $\mathbf{m}$ & V & C & MO \\
\hline & & & \multicolumn{7}{|c|}{$\mathrm{cmol} / \mathrm{dm} 3=\mathrm{mE} / 100 \mathrm{~mL}$} & \multicolumn{2}{|c|}{$\%$} & \multicolumn{2}{|c|}{$\mathrm{g} / \mathrm{kg}$} \\
\hline \multicolumn{14}{|c|}{ Ponto 1: Latossolo Vermelho } \\
\hline $0-20$ & 5,5 & 0,6 & 1 & 0,63 & 5,4 & 0,06 & 0,27 & 7,13 & 1,73 & 26,7 & 24 & 37,1 & 63,8 \\
\hline $40-60$ & 5,5 & 0,7 & 1 & 0,6 & 4 & 0,01 & 0,03 & 5,34 & 1,34 & 30,9 & 25 & 17,6 & 30,3 \\
\hline $60-80$ & 5,6 & 0,9 & 0,5 & 0,1 & 3,7 & 0,01 & 0,04 & 4,55 & 0,85 & 10,5 & 19 & 15,4 & 26,5 \\
\hline $80-100$ & 5,4 & 0,7 & 0,6 & 0 & 4 & 0,01 & 0,04 & 4,95 & 0,95 & 0 & 19 & 18,3 & 31,5 \\
\hline \multicolumn{14}{|c|}{ Ponto 2: Latossolo Vermelho-Amarelo } \\
\hline $0-20$ & 5,4 & 0,7 & 0,7 & 0,6 & 4,3 & 0,02 & 0,11 & 5,43 & 1,13 & 34,7 & 21 & 30,2 & 51,9 \\
\hline $40-60$ & 5,8 & 0,5 & 0,5 & 0 & 2,4 & 0,25 & 0,07 & 3,52 & 1,12 & 0 & 32 & 8,9 & 15,3 \\
\hline $60-80$ & 6 & 0,5 & 1,1 & 0 & 2,2 & 0,02 & 0,06 & 3,68 & 1,48 & 0 & 40 & 8,9 & 15,3 \\
\hline $80-100$ & 5,8 & 0,8 & 0,4 & 0 & 2,5 & 0,02 & 0,05 & 3,27 & 0,77 & 0 & 24 & 4,8 & 8,3 \\
\hline \multicolumn{14}{|l|}{ Ponto 3: Glaissolo } \\
\hline $0-20$ & 5,1 & 13,2 & 0,3 & 2,7 & 6,7 & 0,06 & 0,15 & 7,41 & 0,71 & 79,2 & 10 & 293 & 504 \\
\hline $40-60$ & 4,8 & 2,7 & 0,3 & 6,4 & 11,3 & 0,04 & 0,11 & 11,85 & 0,55 & 92,1 & 5 & 278 & 478 \\
\hline $60-80$ & 4,8 & 1,9 & 0,2 & 9,2 & 12,1 & 0,03 & 0,1 & 12,53 & 0,43 & 95,5 & 3 & 207 & 356 \\
\hline $80-100$ & 4,7 & 1,8 & 0,2 & 9,8 & 10,5 & 0,02 & 0,07 & 10,89 & 0,39 & 96,2 & 4 & 155 & 267 \\
\hline \multirow{2}{*}{$\begin{array}{l}\text { Profundidade } \\
(\mathrm{cm})\end{array}$} & \multirow{2}{*}{$\mathrm{pH} \mathrm{H}_{2} \mathrm{O}$} & \multirow{2}{*}{$P\left(m g / d^{3}\right)$} & $\mathrm{Ca}+\mathrm{Mg}$ & Al & $\mathrm{H}+\mathrm{Al}$ Acidez & $\mathrm{Na}$ & $\mathbf{K}$ & $\mathbf{T}$ & SB & $\mathbf{m}$ & V & C & MO \\
\hline & & & \multicolumn{7}{|c|}{$\mathrm{cmol} / \mathrm{dm} 3=\mathrm{mE} / 100 \mathrm{~mL}$} & \multicolumn{2}{|c|}{$\%$} & \multicolumn{2}{|c|}{$\mathrm{g} / \mathrm{kg}$} \\
\hline \multicolumn{14}{|c|}{ Ponto 1: Latossolo Vermelho } \\
\hline $0-20$ & 5,5 & 0,6 & 1 & 0,63 & 5,4 & 0,06 & 0,27 & 7,13 & 1,73 & 26,7 & 24 & 37,1 & 63,8 \\
\hline $40-60$ & 5,5 & 0,7 & 1 & 0,6 & 4 & 0,01 & 0,03 & 5,34 & 1,34 & 30,9 & 25 & 17,6 & 30,3 \\
\hline $60-80$ & 5,6 & 0,9 & 0,5 & 0,1 & 3,7 & 0,01 & 0,04 & 4,55 & 0,85 & 10,5 & 19 & 15,4 & 26,5 \\
\hline $80-100$ & 5,4 & 0,7 & 0,6 & 0 & 4 & 0,01 & 0,04 & 4,95 & 0,95 & 0 & 19 & 18,3 & 31,5 \\
\hline \multicolumn{14}{|c|}{ Ponto 2: Latossolo Vermelho-Amarelo } \\
\hline $0-20$ & 5,4 & 0,7 & 0,7 & 0,6 & 4,3 & 0,02 & 0,11 & 5,43 & 1,13 & 34,7 & 21 & 30,2 & 51,9 \\
\hline $40-60$ & 5,8 & 0,5 & 0,5 & 0 & 2,4 & 0,25 & 0,07 & 3,52 & 1,12 & 0 & 32 & 8,9 & 15,3 \\
\hline $60-80$ & 6 & 0,5 & 1,1 & 0 & 2,2 & 0,02 & 0,06 & 3,68 & 1,48 & 0 & 40 & 8,9 & 15,3 \\
\hline $80-100$ & 5,8 & 0,8 & 0,4 & 0 & 2,5 & 0,02 & 0,05 & 3,27 & 0,77 & 0 & 24 & 4,8 & 8,3 \\
\hline \multicolumn{14}{|l|}{ Ponto 3: Glaissolo } \\
\hline $0-20$ & 5,1 & 13,2 & 0,3 & 2,7 & 6,7 & 0,06 & 0,15 & 7,41 & 0,71 & 79,2 & 10 & 293 & 504 \\
\hline $40-60$ & 4,8 & 2,7 & 0,3 & 6,4 & 11,3 & 0,04 & 0,11 & 11,85 & 0,55 & 92,1 & 5 & 278 & 478 \\
\hline $60-80$ & 4,8 & 1,9 & 0,2 & 9,2 & 12,1 & 0,03 & 0,1 & 12,53 & 0,43 & 95,5 & 3 & 207 & 356 \\
\hline $80-100$ & 4,7 & 1,8 & 0,2 & 9,8 & 10,5 & 0,02 & 0,07 & 10,89 & 0,39 & 96,2 & 4 & 155 & 267 \\
\hline
\end{tabular}

Onde: $\mathrm{Al}+\mathrm{H}=$ Acidez potencial; $\mathrm{T}$ = Capacidade de troca catiônica; $\mathrm{SB}=$ Soma de Bases; $\mathrm{m}$ = Saturação de alumínio; $\mathrm{V}$ = Saturação de bases; $\mathrm{CO}=$ Carbono Orgânico; $\mathrm{MO}=$ Matéria Orgânica.

Fonte: CARVALHO (2015, pg. 95). 
Geralmente, as Veredas correm em áreas com predominância de Latossolos e Neossolos Quartzarênicos, sendo esse subsistema relacionado aos solos gleis ou orgânicos (RAMOS, 2004; MELO 2008, BOAVENTURA, 2007). Na área em estudo, o solo da zona encharcada foi classificado como Gleissolos, de acordo com Embrapa, 2009. Esse tipo de solo, em geral, é pouco desenvolvido, que se forma a partir de sedimentos aluviais, com presença de lençol freático próximo à superfície, 0 qual caracteriza um ambiente de oxirredução e acumulação de materiais orgânicos.

Normalmente, os processos de oxidação e redução do ferro determinam as características morfológicas desses solos, conferindo-lhes cores distintas. A solubilidade e a cor do ferro são influenciadas pelos seus estados de oxidação, o que explica os matizes cinza, preto, marrom e amarelo, frequentemente observados em solos do tipo glei (BISPO, 2010).

Dos resultados obtidos com a análise dos atributos químicos, enfatizou-se o grau de acidez, por se relacionar com os íons de $\mathrm{Ca}, \mathrm{Mg}, \mathrm{Al}$, que são, entre outros, diretamente responsáveis pelo grau de fertilidade do solo. Esses atributos no geral, não variam muito ao longo do gradiente e da profundidade

Em, praticamente, todos os perfis analisados, o teor de Al foi mais elevado na camada superficial, possivelmente, pela formação de complexos com as substâncias húmicas. Entretanto, no Gleissolo da zona encharcada da Vereda, verificou-se o inverso, os teores de Al foram maiores em profundidade, o que, de acordo com Bispo (2010), ocorre em decorrência da redução de pH.

A comparação das propriedades químicas dos solos, entre as diferentes zonas da Vereda, evidenciou a existência de variações significativas nos teores dos elementos químicos. Segundo Ramos et al. (2014), essas variações, possivelmente, estão associadas a diversos fatores, tais como: sazonalidade do lençol freático, deposição de sedimentos de forma diferenciada e interferência antrópica nas Veredas.

Todos os perfis analisados apresentaram alta concentração de acidez associada ao baixo $\mathrm{pH}$, comum a maioria das classes de solos do Cerrado. Costuma-se argumentar que essa condição, associada à toxicidade de alumínio e à baixa fertilidade do solo são fatores limitantes para o desenvolvimento das plantas. Isso é confirmado no caso de plantas cultivadas, cujo crescimento é afetado pela toxicidade em solos ácidos, mas não para as espécies típicas do Cerrado (HARIDASAN, 2008).

Sabe-se que a vegetação do Cerrado possui vários mecanismos de adaptação como transpiração noturna, reabsorção de nutrientes antes de senescência das folhas e reciclagem de nutrientes a partir da serapilheira. De acordo com Haridasan (2008), o desenvolvimento da maioria das espécies que crescem em solos ácidos não é afetado pela toxicidade do alumínio. Muitas dessas absorvem e acumulam o alumínio em seus tecidos, incluindo em suas folhas e sementes.

Um bom exemplo identificado por Haridasan (2008) é a Miconia albicans (Sw.), uma das espécies mais representativas das Veredas. De acordo com esse autor, essa espécie não cresce na ausência de Al. O autor concluiu, após a realização de experimentos, que os indivíduos dessa espécie não se desenvolvem em solos com calcário, os quais mostraram amarelecimento e necrose de folhas novas. Contudo, quando transplantadas para solos ácidos, nota-se a sua recuperação. Ou seja, possivelmente, outras espécies presentes no ambiente de Vereda devem estar adaptadas à acidez $\mathrm{e}$ à pobreza de nutrientes identificados nos seus solos.

Análises químicas e físicas, em solos de áreas de Veredas vêm sendo realizadas por alguns autores, assim como a relação solo-vegetação. Em Minas Gerais, Ramos et al. (2014) concluiu que os solos das Veredas apresentam níveis médios de acidez, altos níveis de matéria orgânica e de alumínio, baixos níveis de cálcio, magnésio e fósforo.

Considera-se então, que a distribuição dos solos na Vereda apresenta uma íntima relação com o comportamento do lençol freático, como verificado por Melo (2008) Farias et al. (2008) e Augustin et al. (2009). Na zona de fundo, onde o nível freático apresenta-se mais próximo à superfície, ocorrem os Gleissolos, mas com características físicas diferentes.

A amostra de Gleissolo da Vereda apresentou textura Franco-arenosa, cuja alta concentração de areia pode ser resultado da relação existente entre os solos e a litologia. Segundo Mamede (1999), ao se analisar perfis de solo na RECOR, concluiu-se que esses demonstram características advindas da litologia, como a diminuição dos teores de argila e como o domínio absoluto de areia muito fina, em profundidade. Portanto, percebe-se que esses solos foram condicionados às características 
estruturais e mineralógicas da formação geológica constituída, basicamente, por metassiltitos com lentes de arenitos.

Identificou-se que os maiores teores de matéria orgânica foram localizados na zona encharcada da Vereda, devido as piores condições de drenagem ali existentes. A pior aeração do solo tornou mais lenta a decomposição dos resíduos orgânicos, propiciando o acúmulo e formação da turfa (RAMOS et al. 2014; MELO, 2008).

Com relação à sucessão ecológica, a Vereda do córrego Taquara encontra-se em fase avançada, onde o estrato arbóreo já se mostra bem desenvolvido e os buritis ocorrem esparsamente. Verificouse a presença de árvores comum às formações florestais do Cerrado, entretanto, o solo ainda se encontrava alagado em algumas partes, o que favoreceu a permanência da Vereda.

\section{GÊNESE E EVOLUÇÃO}

A formação e a evolução das Veredas nas planícies da bacia do córrego Taquara também estão relacionadas as oscilações climáticas entre fases secas e úmidas, ocorridas durante o Holoceno.. Assim como a reestruturação da drenagem dessa bacia. Primeiramente, durante uma fase mais seca, ocorreu o alargamento dos vales com deposição de materiais detríticos grosseiros e a retração do cerrado (RIBEIRO, 2011).

Conforme abordado por Mamede (apud. RIBEIRO, 2011, p. 83), a partir de $7.220 \pm 70$ AP, sob condições climáticas quentes e úmidas, ocorreu o preenchimento dos vales com materiais orgânicos e minerais finos, originando as aluviões e colúvios remanejados das superfícies aplainadas, ocasionando condições para o surgimento do subsistema de Vereda.

Posterior a outra fase mais seca, há aproximadamente 2.500 anos, o clima passou a ter características tropicais iguais aos atuais, o que possibilitou à retomada dos processos erosivos, como a incisão dos talvegues, entalhamento das vertentes, escoamento concentrado e difuso, bem como o adensamento das formações florestais e sua expansão sobre buritis.

De acordo com Pereira e Furtado (apud. RIBEIRO, 2011), a Mata de Galeria Paludosa tem sua origem atribuída à ocupação de Veredas por espécies arbóreas e arbustivas, as quais são adaptadas a solos encharcados. Após observações na Reserva Ecológica, os autores perceberam que a formação dessa Mata se inicia com o surgimento de agrupamentos de espécies lenhosas junto aos buritizeiros, os quais, com o tempo, coalescem e as Veredas assumem fisionomia e estrutura de floresta. Em alguns trechos de Mata de Galeria Paludosa é comum encontrar buritis adultos, mas sem a presença de indivíduos jovens.

Outros fatores ambientais podem estar colaborando para o processo de sucessão ecológica pelo qual a Vereda em estudo vem passando. A saber, a rede de drenagem continua a evoluir e com a possível definição dos drenos fluviais, o lençol freático superficial passará a ser drenado para o córrego Taquara, fator que ocasiona a diminuição da umidade do solo. A mudança da dinâmica ambiental atual, com a substituição do ambiente úmido para o do bem drenado favorecerá a sucessão do subsistema de Vereda para o de Mata de Galeria Seca.

Além disso, o fogo pode ser outro fator responsável pelo aumento da diversidade das espécies. Pois há maior riqueza de espécies em área de campo sujo sujeitas a queimadas periódicas, do que nas áreas onde não ocorreram queimadas durante longos períodos de tempo. Assim, sabe-se que o fogo pode estimular o surgimento de algumas espécies e retardar o aparecimento de outras (RAMOS, 2004, p. 64).

As queimadas também podem modificar profundamente as condições do solo. Sua passagem diminui a concentração de umidade e matéria orgânica,, abaixa $\circ \mathrm{pH}$ e aumenta por tempo determinado o teor de $\mathrm{K}, \mathrm{P}$ e N assimilável na camada superficial do solo. Mas também é responsável pela redução da capacidade de retenção da água favorecendo o escoamento superficial, o qual lava a superfície e contribui para o empobrecimento definitivo do solo (COSTA e RODRIGUES, 2015).

\section{LEVANTAMENTOS FLORÍSTICO}

Analisou-se que no subsistema de Vereda, a vegetação reflete as condições climáticas, edáficas e geomorfológicas de onde estão localizadas. A proximidade do lençol freático, a saturação do solo

\begin{tabular}{llllll}
\hline Caminhos de Geografia & Uberlândia - MG & v. 19, n. 68 & Dez/2018 & p. 233-249 Página 244
\end{tabular}


praticamente 0 ano todo e a variação da topografia nas diferentes zonas identificadas, são condições que favorecem um gradiente de umidade que contribuem para o aparecimento de gêneros típicos de solos mal drenados, como: Xyris, Drosera, Lycopodiella, Miconia e, espécies brejeiras das famílias Cyperaceae e Poaceae.

No estudo da composição florística da Vereda foram identificadas 57 espécies distribuídas em 24 famílias. As famílias que se destacaram em riqueza de espécies foram: Melastomataceae, Cyperaceae, Lycopodiaceae e Poaceae representando pouco mais de $45 \%$ do total de espécies identificadas (Quadro 1).

Quadro 1: Espécies identificadas na Vereda da RECOR em ordem alfabética de família.

\begin{tabular}{|c|c|c|}
\hline Espécie & Família & Habitat \\
\hline Echinodorus grandiflorus (Cham. \&Schltdl.) Micheli & Alismataceae & Mata de galeria \\
\hline Sagittaria rhombifolia Cham. & Alismataceae & Mata de galeria/Vereda \\
\hline Tapirira guianensis Aubl & Anacardiaceae & Vereda/Mata de galeria \\
\hline Philodendron uliginosum & Araceae & campo limpo úmido \\
\hline Mauritia flexuosa L.f. (buriti) & Arecaceae & Vereda/brejo \\
\hline Achyrocline alata (Kunth) DC. & Asteraceae & Campo limpo \\
\hline $\begin{array}{l}\text { Raulinoreitzia crenulata (Spreng. Ex Hieron.) R.M.King } \\
\text { \& H.Rob. }\end{array}$ & Asteraceae & Mata de galeria/Vereda \\
\hline Vernonia brevifolia Less & Asteraceae & Vereda \\
\hline Blechnum brasilienseDesv. & Blechnaceae & Mata de galeria/Vereda \\
\hline Lobelia brasiliensis A. O.S Vieira \& G.J. & Campanulaceae & Vereda/Mata de Galeria \\
\hline Siphocampylus lycioidesG.Don & Campanulaceae & campo limpo úmido \\
\hline Cecropia pachystachya Trécul & Cecropiaceae & Mata Ciliar/Mata seca \\
\hline Ipomea saopaulista O'Donnell (trepadeira) & Convolvulaceae & cerrado (áreas abertas) \\
\hline Ascolepsis brasiliensis (Kunth) Benth. exC.B.Clark & Cyperaceae & Vereda \\
\hline Bulbostylis selowiana (Kunth) Palla & Cyperaceae & \\
\hline Bulbostylis capillaris (L.) Kunth ex C.B.Clarke & Cyperaceae & Vereda/Campo limpo úmido \\
\hline Eleocharis capillacea Kunth & Cyperaceae & Campo limpo úmido/Vereda \\
\hline Eleocharis filiculmis Kunth & Cyperaceae & Mata de galeria/Vereda \\
\hline Lagenocarpus rigidus Nees & Cyperaceae & Vereda/Campo limpo úmido \\
\hline Rhynchospora emaciata (Ness) Boech & Cyperaceae & \\
\hline Scleria arundinacea Kunth & Cyperaceae & Mata de galeria/Vereda \\
\hline Scleria globosa & Cyperaceae & $\begin{array}{l}\text { Mata de galeria/campo } \\
\text { limpo úmido } \\
\end{array}$ \\
\hline Scleria latifólia Sw. & Cyperaceae & Mata de galeria/campo úmido \\
\hline Websteria cf. conferoides (Poir.) S.S.Hooper & Cyperaceae & Mata de galeria/Vereda \\
\hline Pteridiuma rachnoideum (Kaulf.) Maxon (samambaião) & Dennstaedtiaceae & invasora \\
\hline Drosera montana & Droseraceae & Vereda/campo úmido \\
\hline Equisetum giganteum L. & Equisetaceae & Mata de galeria/Vereda \\
\hline Paepalanthus scandens Ruhland & Eriocaulaceae & Campo limpo úmido/Vereda \\
\hline Syngonanthus helminthorrhizus (Mart.) Ruhland & Eriocaulaceae & Vereda/campo limpo úmido \\
\hline Syngonanthus nitens Ruhland & Eriocaulaceae & Vereda/ campo úmido \\
\hline Croton campestris (A.St.-Hil.) Müll. Arg. & Euphorbiaceae & Cerrado stricto sensu \\
\hline Maproune aguianensis & Euphorbiaceae & Mata de Galeria \\
\hline Acosmium dasycarpum (Lam.) DC. & Fabaceae & $\begin{array}{l}\text { cerrado sentido restrito/ } \\
\text { campo sujo }\end{array}$ \\
\hline
\end{tabular}




\begin{tabular}{|c|c|c|}
\hline Eriosemas tenopyhllum Harms & Fabaceae & cerrado/campo sujo \\
\hline Hypenia macrantha (A.St.-Hil. ex Benth.) Harley & Lamiaceae & campo sujo \\
\hline Hyptis cardiophylla Pohl ex Benth. & Lamiaceae & cerrado/Campo sujo \\
\hline Hyptis linarioides Pohl ex Benth. & Lamiaceae & Campo limpo úmido \\
\hline Lycopodiella lopecuroides (L.) Cranfill. & Lycopodiaceae & campo úmido/brejo \\
\hline Lycopodiella camporumOllgard\&P.G.Windisch & Lycopodiaceae & Campo limpo úmido/Vereda \\
\hline Lycopodiella carolinianum (L.) Picchi-Sermolli & Lycopodiaceae & Campo limpo úmido/Vereda \\
\hline Lycopodiella cernua (L.) Pichi-Sermolli & Lycopodiaceae & Campo limpo úmido/Vereda \\
\hline Miconia burchellii Triana & Melastomataceae & $\begin{array}{l}\text { campo cerrado/campo sujo/ } \\
\text { cerrado sentido restrito/cerradão }\end{array}$ \\
\hline Microlicia euphorbioides Mart. & Melastomataceae & $\begin{array}{l}\text { Campo limpo úmido/ campo } \\
\text { limpo úmido com murundum }\end{array}$ \\
\hline Miconia dodecandra & Melastomataceae & $\begin{array}{l}\text { Mata de Galeria e Floresta } \\
\text { Ombrófila } \\
\end{array}$ \\
\hline Rhynchanthera grandiflora (Aubl.)DC & Melastomataceae & $\begin{array}{l}\text { campo limpo úmido/Vereda/ } \\
\text { Mata de galeria }\end{array}$ \\
\hline Trembleya chamissoana Naudin & Melastomataceae & Cerrado sentido restrito \\
\hline Trembleya parviflora (D. Dor.) Cogn & Melastomataceae & cerrado \\
\hline Trembleya phlogiformis Mart \&Schr. ex. DC & Melastomataceae & $\begin{array}{l}\text { Mata de galeria/campo limpo } \\
\text { úmido }\end{array}$ \\
\hline Ludwigia octovalvis (Jacq.) P.H.Raven & Onagraceae & \\
\hline Andropogon bicornis L. & Poaceae & Campo limpo úmido/Vereda \\
\hline Panicum subtiramulosum Renvoize\&Zuloaga & Poaceae & Campo limpo úmido/Vereda \\
\hline Paspalum proximum Mez & Poaceae & Campo limpo úmido/Vereda \\
\hline Melinis minutiflora P. Beauv. (Capim-gordura) & Poaceae & invasora \\
\hline Pityrogram maebenea (L.) Proctor & Pteridaceae & Vereda/Mata de galeria \\
\hline Solanum lycocarpum St. Hill (Lobeira) & Solanaceae & Todas as fitofisionomias \\
\hline Xyris axifolia Mart. & Xyridaceae & Campo limpo úmido/Vereda \\
\hline Xyris sp.1 & Xyridaceae & Vereda \\
\hline
\end{tabular}

Fonte: CARVALHO (2015, pg. 122).

Essas famílias com maior representatividade são comumente citadas como as que apresentam maior ocorrência em Veredas (GUIMARÃES et al. 2002; RAMOS, 2004).

A comunidade vegetal em estudo apresentou-se muito impactada, com predominância de espécies exóticas pioneiras do Cerrado, como as dos gêneros Trembleya e Lavoisiera, Melinis e Solanum.

A presença de espécies exóticas, como potenciais invasoras, é justificada, geralmente, quando há alta taxa de crescimento relativo; grande produção de sementes pequenas e de fácil dispersão; alta longevidade das sementes no solo; alta taxa de germinação floração e frutificação mais prolongada; alto potencial reprodutivo; pioneirismo; e ausência de inimigos naturais.

A introdução dessas espécies na área em estudo, provavelmente, ocorreu acidentalmente, pois corresponde a uma unidade de preservação ambiental. O estabelecimento das espécies exóticas constitui-se como um fator perturbador à alteração ambiental, pois essas tendem a se multiplicar constantemente, o que causa problemas que se agravam com o tempo e, consequentemente, não permitem que os ecossistemas afetados se recuperem naturalmente. Com relação à Vereda, as plantas exóticas ocorrem de maneira mais dispersa, destacando-se principalmente na zona de borda, em contato com o Cerrado ralo. 
Pereira e Filgueiras (1988 apud Santana, 2007. pg. 49) relataram que existiam 252 espécies exóticas em área de Cerrado stricto sensu da RECOR. Segundo os autores, 44 das gramíneas africanas introduzidas no Brasil, onze apresentavam elevado grau de invasão.

Constatou-se que na Vereda da RECOR, vários fatores permitem explicar o aparecimento das espécies amostradas: a forma favorável de dispersão das sementes (vento, animais e insetos); a ação antrópica, como a abertura de estradas e de aceiros próximos às suas bordas para promover o trânsito de pessoas e carros. É constado que essas situações podem trazer sementes a estes locais e causar a diminuição da umidade do solo.

Países tropicais são excelentes hábitats para as plantas exóticas, devido às condições climáticas e pedológicas. Além disso, as espécies exóticas estão livres de competidores, predadores e parasitas, apresentando vantagens fitofisiológicas competitivas com relação a espécies nativas. No Cerrado, essa situação se agrava, porque as práticas no manuseio desse domínio, como a remoção da vegetação, as queimadas anuais para preparo da terra, a erosão e a pressão excessiva de pastoreio contribuem para a perda de diversidade natural e para a fragilidade do meio a invasões (SANTANA, 2007).

\section{CONSIDERAÇÃOES FINAIS}

Ficou demonstrado que ao longo do transecto selecionado para a Vereda da RECOR os tipos de solos identificados estão diretamente associados à compartimentação topográfica e aos aspectos edáficos da área em estudo. De maneira geral, eles apresentam-se ácidos, com altos níveis de alumínio disponíveis e de teores de matéria orgânica, além de baixa disponibilidade de macronutrientes, indicando baixa fertilidade.

Em relação ao levantamento florístico, foram identificadas 57 espécies, cuja maior parte pertence às famílias Melastomataceae, Cyperaceae, Lycopodiaceae e Poaceae, típicas de ambiente de Vereda. Observou-se que há maior ocorrência de espécies invasoras na zona de contato entre a Vereda e o Cerrado ralo. Essa invasão pode ser evidenciada devido às perturbações antrópicas, como a abertura de estradas nessas áreas.

O processo evolutivo da Vereda está diretamente ligado à evolução das drenagens superficiais. Provavelmente, a sucessão das comunidades vegetais da Vereda está associada ao aprofundamento dos talvegues do córrego Taquara e ao rebaixamento do nível freático, que está sendo drenado pelos cursos d'água e/ou alterado devido ao aumento da ocupação urbana e rural nas proximidades de Unidades de Conservação - UCs. Essa sucessão ecológica pode ser caracterizada pela presença de espécies arbóreas entre os Buritis.

Nota-se que a presença de Veredas na RECOR está associada à proximidade com as Chapadas Elevadas, pois essas correspondem a áreas de recarga de aquífero, de outro modo as Veredas, localizadas nas porções mais baixas do relevo são as áreas de exsudação desses aquíferos. $O$ condicionante geomorfológico é muito importante para a manutenção e gênese das Veredas, pois este subsistema evolui em conjunto com as formas de relevo local.

Por fim, diante do que foi apresentado nesse estudo, deve-se ter consciência da urgência em se preservar o ambiente de Vereda, a fim de recuperar as áreas degradadas para a manutenção dos recursos hídricos da região e garantir a perpetuação de corredores ecológicos do domínio Cerrado. Verifica-se a necessidade da conscientização, por parte do poder público e da própria sociedade, em defesa da preservação desse ambiente.

\section{REFERÊNCIAS}

AUGUSTIN, C. H. R. R.; MELO, D. R.; ARANHA, P. R. A. Aspecto geomorfológico de Veredas: um ecossistema do bioma cerrado, Brasil. Revista Brasileira de Geomorfologia, v. 10, n. 1, 2009.

BISPO, F. H. A. Gênese e classificação de Solos em Topossequência de Veredas das Chapadas do Alto Vale do Jequitinhonha - MG. 2010. 98f. Dissertação (Mestrado em Ciências Agrárias), Universidade Federal dos Vales do Jequitinhonha e Mucuri, Diamantina- MG, 2010.

BOAVENTURA, R. S. Vereda berço das águas. Belo Horizonte: Ecodinâmica, 2007. 264 p.

CARVALHO, A. C. A. Análise Ambiental de um Subsistema de Vereda em Unidades de Conservação: Reserva Ecológica do IBGE-RECOR e Estação Ecológica de Águas Emendadas-

$\begin{array}{llllll}\text { Caminhos de Geografia } & \text { Uberlândia - MG } & \text { v. 19, n. } 68 & \text { Dez/2018 } & \text { p. 233-249 } & \text { Página } 247\end{array}$


ESECAE/DF. 2015. 127f. Dissertação (Mestrado em Geografia), Departamento de Geografia, Universidade de Brasília - UnB, 2015.

COSTA, Y. T; RODRIGUES, S. C. Efeito do Fogo Sobre Vegetação e Solo a partir de Estudo Experimental em Ambiente de Cerrado. Revista do Departamento de Geografia/USP, v. 30, 2015.

EMBRAPA - EMPRESA BRASILEIRA DE PESQUISA AGROPECUÁRIA. Centro Nacional de Pesquisa de Solos. Manual de Métodos de Análise de Solo. 2. ed. Rio de Janeiro: EMBRAPACNPS, 1997. 212 p. 2009. $212 \mathrm{p}$.

Sistema Brasileiro de Classificação de Solos. 2. ed. Rio de Janeiro: EMBRAPA-SPI,

FARIAS, M. F. R.; CARVALHO, A. P. F.; CARVALHO. O. A.; MARTINS, E. S.; GOMES, R. A. T. Relação entre os Solos e Fitofisionomias do Parque Nacional de Brasília. Boletim de Pesquisa e Desenvolvimento. Planaltina: EMBRAPA Cerrados, 2008.

FERREIRA, I. M. Modelos geomorfológicos das Veredas no ambiente de Cerrado. Espaço em Revista, Catalão, v. 7/8, n. 1, p. 7-16, jan/dez. 2005/2006.

FILGUEIRAS, T. S.; BROCHADO, A. L.; NOGUEIRA, P. E.; GUALA, G.F. Caminhamento: um método expedito para levantamentos florísticos qualitativos. Cadernos de Geociências, Rio de Janeiro, n. 12, p. 39-44, out/dez. 1994.

GUIMARÃES, A. J. M. ARAÚJO, G. M.; CORRÊA, G. F. Estrutura Fitossociológica em área natural e antropizada de uma vereda em Uberlândia, MG. Acta Botânica Brasília, São Paulo, v. 16, n. 3, p. 317-329, jul. /set. 2002.

HARIDASAN, M. Nutritional adaptations of native plants of the cerrado biome in acid soils.Revista Brasileira de Fisiologia Vegetal, v. 20, p. 183-195, 2008.

MAMEDE, L. Análise e Interpretação Geomorfológica da Bacia do Córrego Taquara - DF. 1999. Tese (Doutorado em Geografia Física), Faculdade de Filosofia Letras e Ciências Humanas, Departamento de Geografia, Universidade de São Paulo, São Paulo, 1999.

MARTINS, R. A. Aplicação do Geoprocessamento no Estudo Integrado das Áreas de Preservação Permanente nos Municípios de Morrinhos e Caldas Novas-GO. 2010.171f. Dissertação (Mestrado em Geografia), Departamento de Geografia, Universidade Federal de Goiás, Catalão- GO, 2010.

MARTINS, R. A; LARANJA, R. E. P; SANTOS, E. V; FERREIRA, I. M; LIMA, J.D. O (Des) Caminho das Águas: alteração no subsistema de vereda provocado por reservatório destinado ao abastecimento de pivô central. Revista Caminhos de Geografia. v.18, n.61, p. 82-101, 2017. https://doi.org/10.14393/RCG186106

MELO, D. R.Evolução das Veredas Sob Impactos Ambientais nos Geossistemas Planaltos de Buritizeiro/MG. 2008. 341f. Tese (Doutorado em Geografia), Instituto de Geociências, Departamento de Geografia, Universidade Federal de Minas Gerais, 2008.

MUNSELL SOIL COLOR COMPANY, Munsell soil color chats, Baltimore, Maryland, USA. 2000.

RAMOS, M. V. V. Caracterização dos Solos, da Estrutura Fitossociológica e do Estado Nutricional da Vegetação de Veredas em Diferentes Superfícies Geomorfológicas no Triângulo Mineiro. 2004. 140f. Tese (Doutorado em Ecologia), Departamento de Ecologia, Universidade de Brasília, 2004.

RAMOS, M. V. V; HARIDASAN, M; ARAÚJO, G. M. Caracterização dos Solos e da Estrutura Fitossociológica da Vegetação de Veredas da Chapada do Triângulo Mineiro. Fronteiras: Journal of Social, Technological and Environmental Science, v.3, n.2, 2014.

RIBEIRO, M. L (Org.). Reserva Ecológica do IBGE. Biodiversidade Terrestre. Rio de Janeiro: IBGE, v. 1, 2011.

RIBEIRO, J.F.; WALTER, B.M.T. As Principais Fitofisionomias do Bioma Cerrado. In: SANO S. M. et al. (Org.). Cerrado: ecologia e flora. Brasília, DF. Embrapa Informação Tecnológica, 2008, p. 151212. 
SANTANA, O. A. Influência de Depósitos de Lixo na Fitofisionomia das Espécies Arbóreas de Cerrado. 2007. 113f. Tese (Doutorado em Engenharia Florestal), Faculdade de Tecnologia, Departamento de Engenharia Floresta, Universidade de Brasília, Brasília- DF.

SANTOS, E. V. O Caminho das Águas: Análise da Modelagem Geomorfológica do Subsistema Vereda no Município de Goiandira, GO. 2010. 147f. Dissertação (Mestrado em Geografia), Departamento de Geografia, Universidade Federal de Goiás, 2010.

SEGETH - Secretaria de Estado de Gestão do Território e Habitação. Geoportal. Disponível em: < http://www.geoportal.segeth.df.gov.br/mapa/> Acessado em: 30 set 2018.

Recebido em: 12/12/2017

Aceito para publicação em: 21/11/2018 